\title{
Evaluating Concrete Quality using Nondestructive In-situ Testing Methods
}

\section{Evaluación de la Calidad del Concreto Utilizando Métodos de Prueba in situ no Destructivos}

Presentación: 03/04/2019

Aprobación: 09/09/2019

\section{Khalid Abdel Naser Abdel Rahim}

Department of Civil Engineering, Faculty of Science and Technology, University of Coimbra, Portugal khalid.ar@outlook.com

\begin{abstract}
This manuscript investigate the quality of concrete using non-destructive in-situ testing. The in-situ testing is a process by which different test are carried out such as rebound hammer, ultrasonic pulse velocity, initial surface absorption test and fig air, to determine the in-situ strength, durability and deterioration, air permeability, concrete quality control and performance. Additionally, the quality of concrete was researched using test methods with experimental results. Moreover, this research has found that (1) the increase in w/c ratio leads to a decrease in compressive strength and ultrasonic pulse velocity. Thus, lower w/c ratio gives a better concrete strength in terms of quality, (2) the quicker the ultrasonic pulse travels through concrete indicates that the concrete is denser, therefore, better quality, (3) the lower initial surface absorption value indicates a better concrete with respect to porosity and (4) the w/c ratio plays an important role in the strength and per-meability of concrete.
\end{abstract}

Keywords: Concrete quality, rebound hammer test, ultrasonic pulse velocity, initial surface absorption test, fig air test.

\section{RESUMEN}

Este manuscrito investiga aspectos de la calidad del hormigón utilizando ensayos in situ no destructivos. Los ensayos in situ aplican un proceso mediante el cual se realizan diferentes pruebas, como martillo de rebote, velocidad de pulso ultrasónico, absorción inicial superficial de agua y permeabilidad al aire de Figg, para determinar la resistencia, durabilidad y deterioro in situ, permeabilidad del aire. Además, esta investigación ha comprobado que (1) el aumento en la relación w/c conduce a una disminución en la resistencia a la compresión y la velocidad del pulso ultrasónico. Por lo tanto, una relación w /c más baja 
proporciona una mejor resistencia del hormigón en términos de calidad, (2) cuanto más rápido viaja el pulso ultrasónico indica que el hormigón es más denso, por lo tanto, mejor calidad, (3) la absorción inicial superficial de agua cuanto más más bajo su valor indica un mejor hormigón con respecto a la porosidad y (4) en definitiva la relación w/c desempeña un papel importante en la resistencia y permeabilidad del hormigón.

Palabras clave: calidad del concreto, prueba de martillo de rebote, velocidad de pulso ultrasónica, prueba de absorción de superficie inicial, prueba de aire de higo.

\section{INTRODUCTION}

\section{Scope of work}

The BS 1881: Part 201: 1986 Guide to the use of non-destructive methods of test for hardened con-crete is set to consider the methods of in-situ testing in terms of advantages, limitations and principal ap-plication. This research is a continuation of three ex-perimental investigations (1) Experimental study on the mix design and fresh properties of concrete, (2) Concrete Specification and Methods of Quality Testing and (3) Experimental Study: Determination of Concrete Reinforcement Conditions ; which were carried out by (Khalid Abdel Naser, 2019). The in-situ testing in the structures laboratory consisted of four tests rebound hammer, ultrasonic pulse velocity, initial surface velocity test (ISAT) and figg air. The testing has been carried out on four concrete specimens with w/c ratios of $0.4,0.45,0.6$ and 0.75 . The dimensions of the squared non-reinforced concrete specimens were $300 \times 300 \mathrm{~mm}$ with a height of $300 \mathrm{~mm}$. In addition, the cement type which was used in the concrete specimens was Portland cement.

In the first section of this report, the procedures of each test carried out in the lab will be presented. Moreover, the advantages and limitations of each in-situ test will be discussed. The results obtained in the lab for each test will be presented, along with a brief discussion on what they mean and indicate. Furthermore, the results will be compared in terms of concrete quality and strength. Finally, the affected quality by concrete strength and relationships between strength test and permeation tests will be reported.

\section{Aims of the paper}

The main objectives of the manuscript are:

-Achieve a better understanding of the in-situ testing process.

-Obtain a greater in-depth knowledge of the in-situ testing procedures and tests carried out in structures laboratory.

-Be able to carry out rebound hammer, ultra-sonic pulse velocity, initial surface absorption and fig air tests.

-Become familiar with the quality and strength of concrete using such tests.

-Be able to define advantages and limitations of each in-situ test.

-Finding out how does strength of concrete affect quality.

-Distinguishing the relationships between the strength tests and permeation tests. 


\section{METHODS AND PROCEDURES OF THE TESTS CARRIED OUT}

\section{Rebound Hammer Test}

The push of plunger against the concrete surface causes the release of compression spring and impact of plunger. As demonstrated in figure 1, the plunger responds in the other position of spring as pushed against concrete surface which activates the hammer mass to impact against the concrete. As the mass of spring controller rebounds, the rider on guide rod moves with it. The rider can then be stopped by pressing the locking button and the rebound can then be recorded. The higher the rebound number, the better the compressive strength according to Bungey et al. (2006). Furthermore, the test was carried out in accordance to BS 1881: Part 202 - Determination of Rebound Number. Firstly, the hammer has been attached firmly in a perpendicular position to a smooth surface on the concrete and the pressure was gradually increased until the plunger impact.

After impact of the plunger the locking button was pressed and the rebound value was recorded. The rebound value was then compared with a hammer rebound vs. compressive strength scale graph (correlation graph) which was on the hammer machine to obtain the compressive strength of a certain rebound value. The rebound number has been taken at 9 locations for two surfaces on the concrete cube and the average of each surface has been calculated.

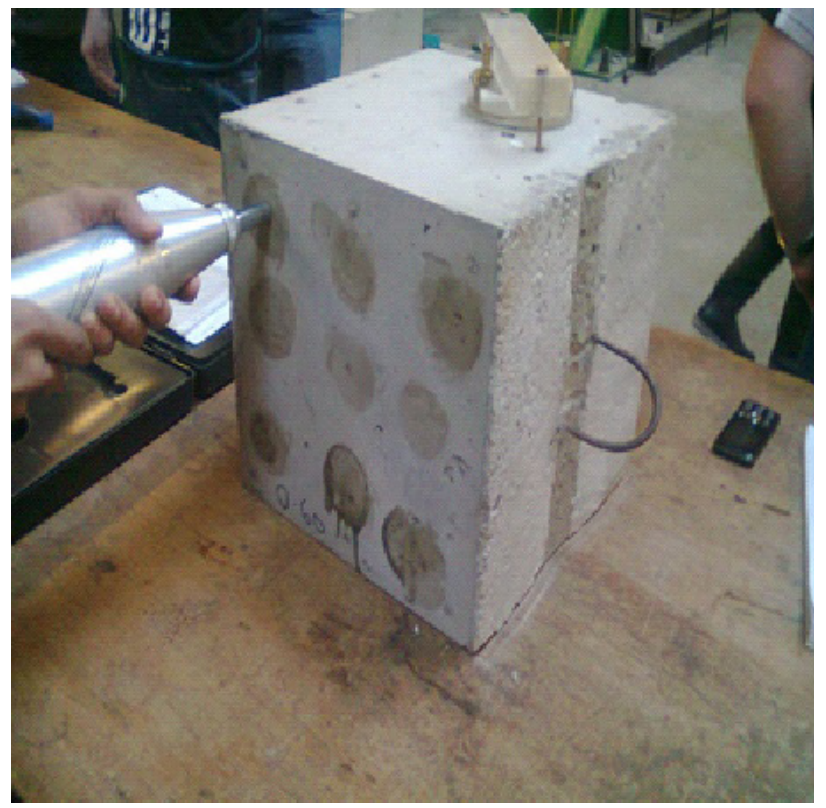

Figure 1. Shows the pressure applied on the concrete by the rebound hammer.

\section{Ultrasonic Pulse Velocity Test}

The ultrasonic pulse velocity is set to find the internal of concrete and velocity of waves. It works by measuring the time taken for a pulse to travel through concrete. There are three ways of measuring the ultrasonic pulse velocity by direct method, semi-direct and indirect. As both the transducers and receiver in linked with concrete surfaces for a direct 
measurement, the transducer starts to send ultrasonic pulses through concrete. The pulse travels through concrete to the receiver on the other face of concrete. Once the pulse is received by receiver, the time taken for pulse to travel from first face to the opposite face is measured. The depth of concrete can then be divided by time to obtain the ultrasonic pulse velocity. The test was carried out in accordance to BS 1881: Part 203 - Recommendations for measurement of ultrasonic pulses in concrete. First of all a good amount of gel has been applied to the transducers surfaces. After that the transducers was connected at each end of the cylindrical steel specimen and the SET REF was adjusted at 26.2 seconds. Again an amount of gel was applied on the transducer and receiver surfaces. Then the transducer and receiver were positioned parallel to each other on opposite faces of the concrete surface. Afterwards the pulse which travelled through the concrete cube was recorded as shown in figure 2. The following procedure has been carried out for nine different locations on each concrete cube and the average has been calculated with reference to the concrete society (2000).

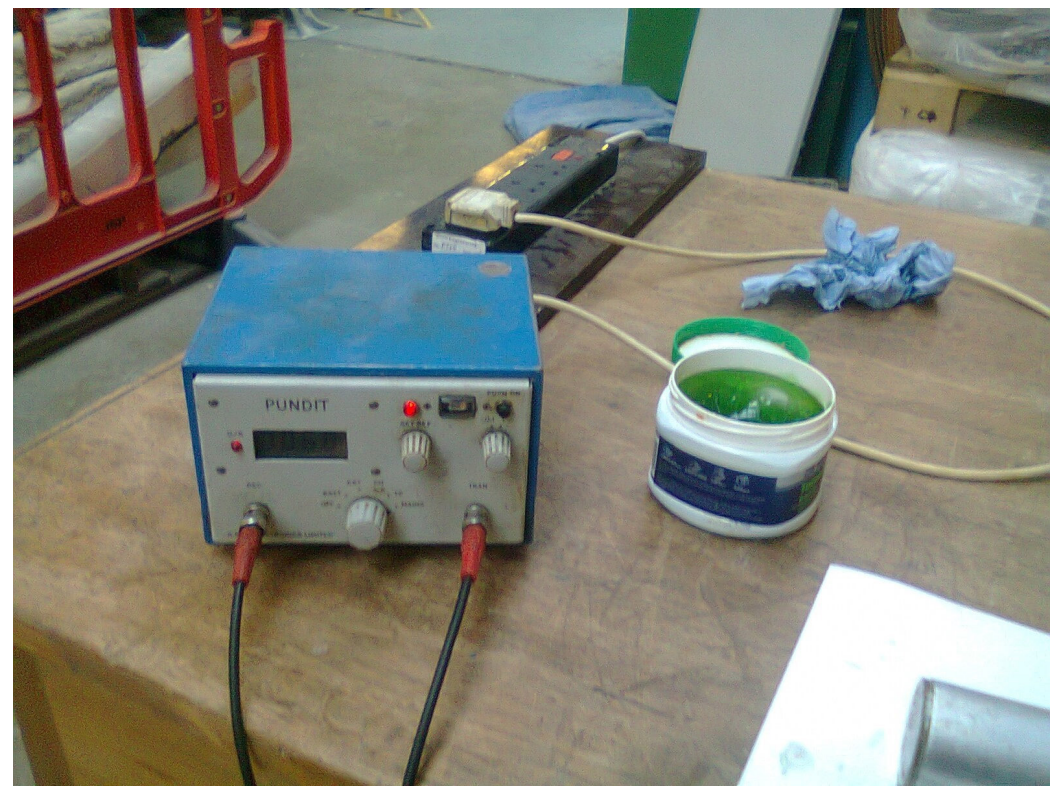

Figure 2. Shows the pundit machine of the ultrasonic pulse velocity test.

\section{Initial Surface Absorption Test (ISAT)}

The initial surface absorption test is used to determine the surface absorption of external part of concrete, porosity and determine cracks. Figure 3 illustrates the apparatus used to carry out the initial surface absorption test. The test was carried out in accordance to BS 1881: Part 208 - Recommendations for the determination of the initial surface absorption of concrete.

Initially, the adjustment of the apparatus has been ensured. Then rubber seal was gently lubricated to the cap of the test apparatus and it was located centrally on side surface of the test cube. After that it was fastened tightly in position to make sure that the seal is water tight. 
The next step was to position the tripod stand on top of the cube, closing reservoir tape and filling reservoir with tape water. Afterwards the tape was opened and the flow of water through rubber tubing was relieved by pinching and raising reservoir. Then once the water reached the concrete surface the stopwatch was started. After 9 minutes the tape was closed, the first reading was taken and the distance water surface travelled along the capillary tube in 1 minute and 2 minutes was recorded in accordance to (Judith, 2010).

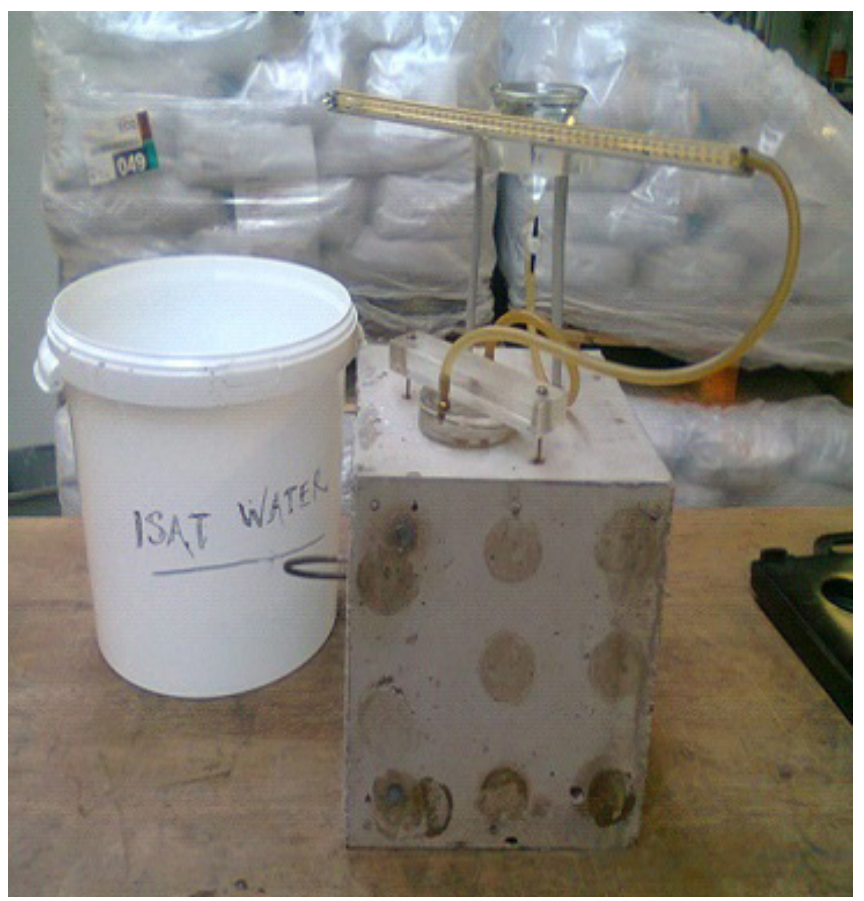

Figure 3. Shows the apparatus used to carry out the Initial surface absorption test.

\section{Figg Air Test}

The Figg air test is commonly used to obtain permeability of concrete surface (Figure 4). This is done by measuring the time taken for air pressure inside a vacuum hole in concrete to increase by a certain pressure, for example, measurement of the time taken for the pressure to increase from $-60 \mathrm{Kpa}$ to $-55 \mathrm{Kpa}$. The time measured indicates air permeability of concrete.

A testing hole with a diameter of $10 \mathrm{~mm}$ approximately and a depth of $40 \mathrm{~mm}$ was drilled inside the concrete cube. Then using a rubber seal, the hole was covered. After that a hypodermic needle was inserted through the rubber seal inside the hole. Afterwards, the air pressure inside the hole has been reduced to $-55 \mathrm{Kpa}$ using a handoperated vacuum pumper with a steady and gentle hand stokes. Subsequently, the time taken for pressure to increase from -55Kpa to $-50 \mathrm{Kpa}$ has been measured using a stop watch and recorded. The following procedure was carried out for two hole in the concrete specimen Bungey et al. (2006). 


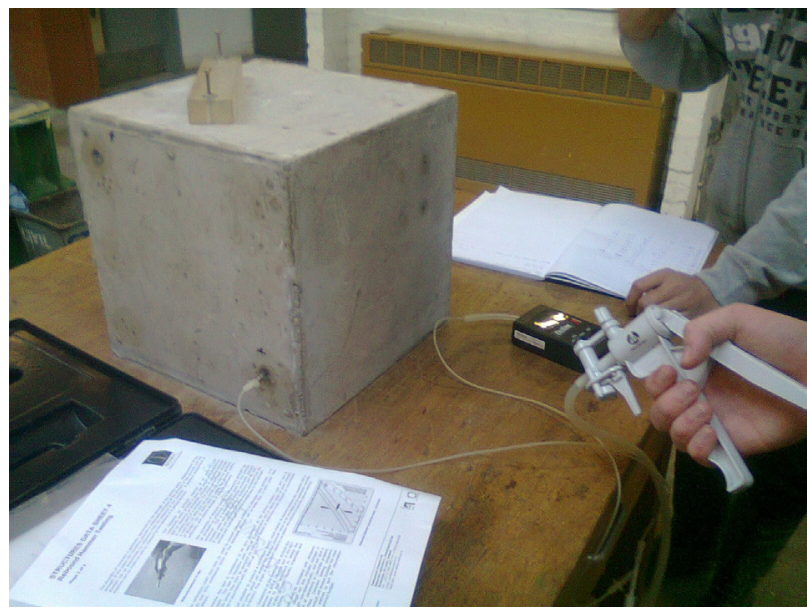

Figure 4. Shows the procedures used for the fig air test.

\section{ADVANTAGES AND LIMITATIONS OF EACH IN-SITU TEST}

\section{Rebound Hammer}

The main usage of rebound hammer test is to measure the surface region hardness of concrete. The rebound number is directed by the stiffness and strength of concrete. This test have many advantages, such as, it is simple method of testing, quick in operation and cost effective. On the other hand, problems such as variability can occur, influenced by aggregate size, concrete type, moisture levels of specimen and surface quality. Moreover, a true estimation of concrete strength can not be obtained using this test. Finally, the verticality position of the hammer can have an effect on the rebound number, by giving results will errors and not close to reality as stated by Neville (1996) and BS 1881: Part 124.

\section{Ultrasonic Pulse Velocity}

The ultrasonic pulse velocity test is related to concrete density and is set to determine internal quality of concrete element. This may include measuring the concrete uniformity, dynamic physical properties, strength of in-situ concrete elements, transformation in properties with time and presence of cracks or voids. The advantages of this test are its reliability as a method of testing internal part of the concrete in a nondestructive way. Moreover, it is considered to be easy in terms of operating quick and reasonably cheap. The limitations that can influence the measurement of pulse velocity are the size and shape of specimen, content of moisture, voids and cracks. Additionally, the huge number of variables can result in boundary predictions of concrete strength and affects the relationship between pulse velocity and strength. Finally, this test requires a good surface contact between concrete surface, transmitter and receiver with respect to BS 1881: Part 203.

\section{Initial Surface Absorption Test (ISAT)}

Initial surface absorption test is generally used to measure the surface absorption of the 
external part of concrete and flow of water rate in concrete specimen. It is an ideal test to measure the porosity of concrete and to detect cracks and voids. The advantages of ISAT are that it is reasonable in cost, simple in operation and quick test in terms of procedures. Alternatively, the result can be affected by the moisture content of concrete in accordance to Neville (1996).

\section{Figg Air Test}

This test is mostly used to find the relationships between air pressure and time, to obtain the permeability of concrete surface and mass and to give predictions on concrete durability. Moreover, it is used to provide indication of the air permeability in the concrete. The advantages of fig air test are that it is moderate in cost, simple in operation and quick test in terms of procedures. On the other hand, the result can be influenced by the moisture content of concrete with reference to Neville (1996).

\section{RESULTS FOR EACH CONCRETE SPECIMEN}

\section{Rebound hammer}

Tables 1 to 4 shows the rebound hammer test results obtained in the lab for concrete specimens of $0.4,0.45,0.60$ and $0.75 \mathrm{w} / \mathrm{c}$ ratios.

\begin{tabular}{|c|c|c|c|}
\hline \multicolumn{2}{|c|}{ Face 1} & \multicolumn{2}{|c|}{ Face 2} \\
\hline Rebound Number & $\begin{array}{l}\text { Compressive Strength } \\
\qquad \begin{array}{c}{\left[\mathrm{N} / \mathrm{mm}^{2}\right]} \\
\left(\alpha=90^{\circ}\right)\end{array}\end{array}$ & Rebound Number & $\begin{array}{l}\text { Compressive Strength } \\
\qquad \begin{array}{c}{\left[\mathrm{N} / \mathrm{mm}^{2}\right]} \\
\left(\alpha=90^{\circ}\right)\end{array}\end{array}$ \\
\hline 54 & 62 & 49 & 50 \\
\hline 55 & 64 & 50 & 53 \\
\hline 51 & 55 & 51 & 55 \\
\hline 49 & 50 & 47 & 46 \\
\hline 52 & 57 & 52 & 57 \\
\hline 55 & 64 & 50 & 53 \\
\hline 54 & 62 & 50 & 53 \\
\hline 51 & 55 & 53 & 59 \\
\hline 55 & 64 & 51 & 55 \\
\hline Average & 59.2 & Average & 53.4 \\
\hline \multicolumn{4}{|c|}{$\begin{array}{l}\text { Therefore, the Average Compressive Strength }\left(\mathrm{N} / \mathrm{mm}^{2}\right)= \\
{[(\text { Compressive strength at face } 1)+(\text { Compressive strength at face } 2)] / 2=(59.2+53.4) / 2=56 \mathrm{~N} /} \\
\mathrm{mm}^{2}\end{array}$} \\
\hline
\end{tabular}




\begin{tabular}{|c|c|c|c|}
\hline \multicolumn{2}{|c|}{ Face 1} & \multicolumn{2}{|c|}{ Face 2} \\
\hline $\begin{array}{c}\text { Rebound Num- } \\
\text { ber }\end{array}$ & $\begin{array}{l}\text { Compressive Strength } \\
\qquad \begin{array}{c}{\left[\mathrm{N} / \mathrm{mm}^{2}\right]} \\
\left(\alpha=90^{\circ}\right)\end{array}\end{array}$ & Rebound Number & $\begin{array}{l}\text { Compressive Strength } \\
\qquad \begin{array}{c}{\left[\mathrm{N} / \mathrm{mm}^{2}\right]} \\
\left(\alpha=90^{\circ}\right)\end{array}\end{array}$ \\
\hline 44 & 52 & 48 & 48 \\
\hline 51 & 54 & 48 & 48 \\
\hline 49 & 51 & 48 & 48 \\
\hline 51 & 54 & 48 & 48 \\
\hline 55 & 64 & 50 & 52 \\
\hline 50 & 52 & 44 & 40 \\
\hline 46 & 44 & 48 & 48 \\
\hline 50 & 52 & 49 & 49 \\
\hline 54 & 62 & 48 & 48 \\
\hline Average & 53.9 & Average & 47.7 \\
\hline
\end{tabular}

Therefore, the Average Compressive Strength $\left(\mathrm{N} / \mathrm{mm}^{2}\right)=$

$[($ Compressive strength at face 1$)+($ Compressive strength at face 2$)] / 2=(53.9+47.7) / 2=51 \mathrm{~N} / \mathrm{mm}^{2}$

Table 2. Results of rebound hammer test for $0.45 \mathrm{w} / \mathrm{c}$ ratio.

\begin{tabular}{|c|c|c|c|}
\hline \multicolumn{2}{|c|}{ Face 1} & \multicolumn{2}{|c|}{ Face 2} \\
\hline $\begin{array}{l}\text { Rebound } \\
\text { Number }\end{array}$ & $\begin{array}{l}\text { Compressive Strength } \\
\qquad \begin{array}{c}{\left[\mathrm{N} / \mathrm{mm}^{2}\right]} \\
\left(\alpha=90^{\circ}\right)\end{array}\end{array}$ & Rebound Number & $\begin{array}{l}\text { Compressive Strength } \\
\qquad \begin{array}{c}{\left[\mathrm{N} / \mathrm{mm}^{2}\right]} \\
\left(\alpha=90^{\circ}\right)\end{array}\end{array}$ \\
\hline 44 & 40 & 42 & 34 \\
\hline 46 & 50 & 44 & 40 \\
\hline 40 & - & 46 & 48 \\
\hline 45 & 42 & 42 & 34 \\
\hline 46 & 48 & 46 & 48 \\
\hline 48 & 50 & 45 & 42 \\
\hline 49 & 52 & 42 & 34 \\
\hline 45 & 42 & 43 & 35 \\
\hline 44 & 40 & 42 & 34 \\
\hline Average & 45.5 & Average & 38.8 \\
\hline
\end{tabular}

Table 3. Results of rebound hammer test for $0.60 \mathrm{w} / \mathrm{c}$ ratio. 


\begin{tabular}{|c|c|c|c|}
\hline \multicolumn{2}{|c|}{ Face 1} & \multicolumn{2}{|c|}{ Face 2} \\
\hline $\begin{array}{c}\text { Rebound Num- } \\
\text { ber }\end{array}$ & $\begin{array}{l}\text { Compressive Strength } \\
\qquad \begin{array}{c}{\left[\mathrm{N} / \mathrm{mm}^{2}\right]} \\
\left(\alpha=90^{\circ}\right)\end{array}\end{array}$ & $\begin{array}{c}\text { Rebound Num- } \\
\text { ber }\end{array}$ & $\begin{array}{l}\text { Compressive Strength } \\
\qquad \begin{array}{c}{\left[\mathrm{N} / \mathrm{mm}^{2}\right]} \\
\left(\alpha=90^{\circ}\right)\end{array}\end{array}$ \\
\hline 37 & 26 & 36 & 25 \\
\hline 42 & 36 & 39 & 30 \\
\hline 40 & 32 & 40 & 32 \\
\hline 39 & 30 & 36 & 25 \\
\hline 40 & 32 & 38 & 28 \\
\hline 40 & 32 & 40 & 32 \\
\hline 38 & 28 & 38 & 28 \\
\hline 41 & 33 & 39 & 30 \\
\hline 44 & 40 & 48 & 48 \\
\hline Average & 32.1 & Average & 30.9 \\
\hline \multicolumn{4}{|c|}{$\begin{array}{l}\text { Therefore, the Average Compressive Strength }\left(\mathrm{N} / \mathrm{mm}^{2}\right)= \\
{[(\text { Compressive strength at face } 1)+(\text { Compressive strength at face } 2)] / 2=(32.1+30.9) / 2=32 \mathrm{~N} /} \\
\mathrm{mm}^{2}\end{array}$} \\
\hline
\end{tabular}

Table 4. Results of rebound hammer test for $0.75 \mathrm{w} / \mathrm{c}$ ratio.

Tables 1 to 4 show the results obtained in structures lab for rebound hammer test. The results demonstrate rebound number against compressive strength for $\mathrm{w} / \mathrm{c}$ ratios concrete specimens of $0.40,0.45,0.60$ and 0.75 . As shown in table 1 for different regions of $0.4 \mathrm{w} / \mathrm{c}$ ratio concrete cube, the values was slightly close in terms of rebound number value. Thus, the compressive strength at these regions was obviously in the same range. The average compressive strength for face 1 and 2 was 59.2 and $53.4 \mathrm{~N} / \mathrm{mm} 2$ respectively. Therefore, the average compressive strength for this concrete cube was $56 \mathrm{~N} / \mathrm{mm} 2$. According to table 5 , the value of $56 \mathrm{~N} / \mathrm{mm} 2$ demonstrates a very good concrete quality. For $0.45 \mathrm{w} / \mathrm{c}$ ratio cube as shown in table 2 the average compressive strength was $51 \mathrm{~N} / \mathrm{mm} 2$. Hence, this has a very good concrete quality in accordance to table 5 . The results for concrete cube with $0.60 \mathrm{w} / \mathrm{c}$ ratio as can be seen in table 3 had a value of $42 \mathrm{~N} / \mathrm{mm} 2$ for the average compressive strength. Moreover, it is still consider being very good in terms of concrete quality as stated in table 5. Finally, the average compressive strength for $0.75 \mathrm{w} / \mathrm{c}$ ratio was $32 \mathrm{~N} / \mathrm{mm} 2$ as show in table 4. In accordance to table 5 this expresses the concrete as to be of good quality.

Generally speaking, the $0.4 \mathrm{w} / \mathrm{c}$ ratio concrete cube showed the highest average compressive strength among the other concrete specimens of different w/c ratio with a $56 \mathrm{~N} / \mathrm{mm}^{2}$. According to the above results (tables 1-4) as the w/c ratio increases the compressive strength decreases. As shown in graph 1 this indicates that the lower w/c ratio the better concrete is in terms of stiffness and strength. 
w/c ratio vs. Average Compressive Strength

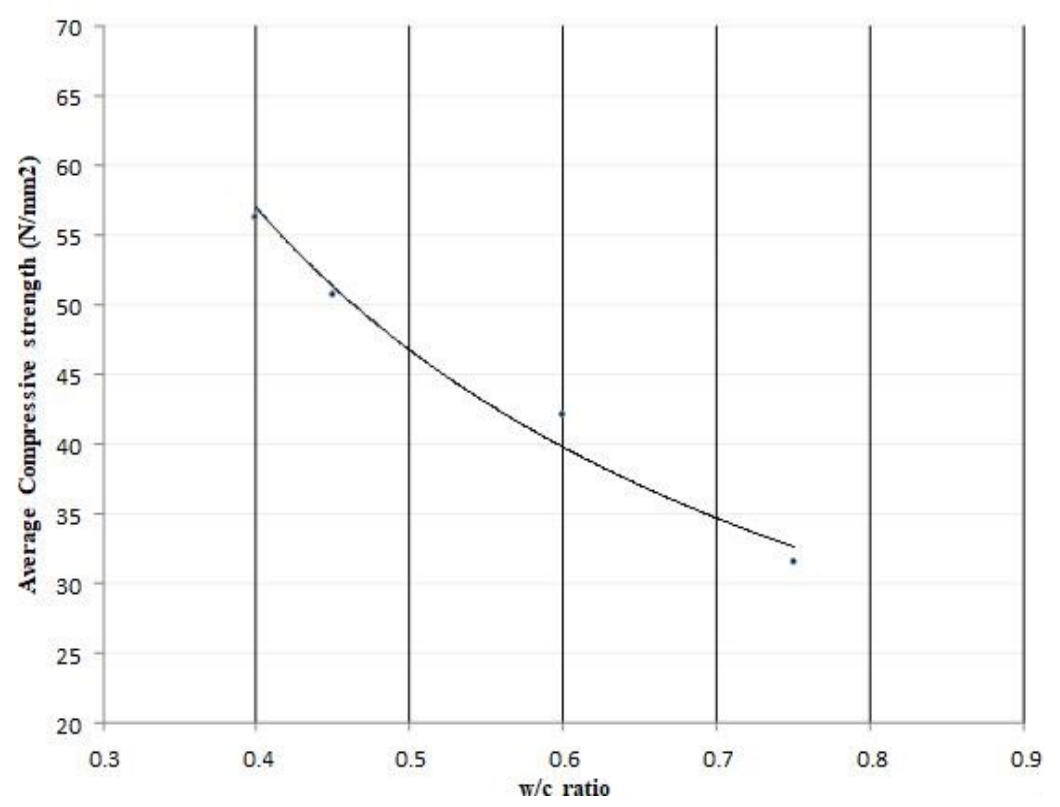

Graph 1. The graph shows the w/c ratio vs. average compressive strength.

\begin{tabular}{|l|l|}
\hline \multicolumn{1}{|c|}{ Average Rebound Number } & \multicolumn{1}{c|}{ Quality of Concrete } \\
\hline Above 40 & Very good \\
\hline Between 30 and 40 & Good \\
\hline Between 20 and 30 & Fair \\
\hline Less than 20 & Poor and / or delaminated \\
\hline
\end{tabular}

Table 5. The table shows relationship between average compressive strength and the strength of concrete by The Concrete Society (2000).

\section{UPV - Ultrasonic pulse velocity}

Tables 6 shows the ultrasonic pulse velocity test results obtained in the lab for concrete specimens of $0.4,0.45,0.60$ and $0.75 \mathrm{w} / \mathrm{c}$ ratios. While equation 1 below was used to calculate the velocity for each test:

Velocity $(\mathrm{m} / \mathrm{s})=$ Depth of concrete $(\mathrm{m}) /$ Average UPV $(\mathrm{s})$ 


\begin{tabular}{|l|l|l|l|l|}
\hline \multicolumn{1}{|c|}{ No. } & \multicolumn{1}{c|}{$0.40 \mathrm{w} / \mathrm{c}$} & \multicolumn{1}{c|}{$0.45 \mathrm{w} / \mathrm{c}$} & \multicolumn{1}{c|}{$0.60 \mathrm{w} / \mathrm{c}$} & \multicolumn{1}{c|}{$0.75 \mathrm{w} / \mathrm{c}$} \\
\hline 1 & 83.5 & 75.8 & 82.6 & 74.5 \\
\hline 2 & 81.3 & 73.6 & 85.0 & 75.7 \\
\hline 3 & 83.3 & 70.4 & 85.0 & 76.3 \\
\hline 4 & 84.4 & 69.9 & 80.3 & 73.6 \\
\hline 5 & 82.2 & 68.8 & 79.4 & 71.9 \\
\hline 6 & 84.8 & 69.3 & 82.5 & 72.4 \\
\hline 7 & 79.4 & 69.2 & 83.3 & 76.3 \\
\hline 8 & 80.7 & 69.1 & 84.3 & 73.8 \\
\hline 9 & 80.4 & 70.0 & 88.4 & 73.6 \\
\hline Average & 70.7 & 74.2 & 82.2 & 83.4 \\
\hline Velocity & $4243 \mathrm{~m} / \mathrm{s}$ & $4043 \mathrm{~m} / \mathrm{s}$ & $3650 \mathrm{~m} / \mathrm{s}$ & $3597 \mathrm{~m} / \mathrm{s}$ \\
\hline
\end{tabular}

Table 6. Results of ultrasonic pulse velocity test for $0.40 \mathrm{w} / \mathrm{c}, 0.45 \mathrm{w} / \mathrm{c}, 0.60 \mathrm{w} / \mathrm{c}$ and $0.75 \mathrm{w} / \mathrm{c}$ ratios.

Table 6 illustrate the results obtained in structures lab for ultrasonic pulse velocity with $\mathrm{w} / \mathrm{c}$ ratios concrete specimens of $0.40,0.45,0.60$ and 0.75 . In table 6 the ultrasonic pulse velocity for $0.4 \mathrm{w} / \mathrm{c}$ ratio was $4.24 \mathrm{~km} / \mathrm{s}$. In respect with table 7 the value of $4.24 \mathrm{~km} / \mathrm{s}$ shows a good quality of concrete. For $0.45 \mathrm{w} / \mathrm{c}$ ratio, the velocity was $4.04 \mathrm{~km} / \mathrm{s}$. Hence, the velocity of 4.04 is still considered to be of a good concrete in terms of quality in accordance to table 7. Moreover, the result for $0.60 \mathrm{w} / \mathrm{c}$ ratio with a velocity of $3.65 \mathrm{~km} / \mathrm{s}$ which is considered to be fair in concrete quality as referred in table 7 . The results for $0.75 \mathrm{w} / \mathrm{c}$ ratio had a velocity of $3.6 \mathrm{~km} / \mathrm{s}$, which indicates a fair concrete quality. Generally, the $0.75 \mathrm{w} / \mathrm{c}$ ratio concrete cube showed the lowest ultrasonic pulse velocity among the other concrete specimens of different w/c ratio with a $3.6 \mathrm{~km} / \mathrm{s}$. It is known that the quicker the ultrasonic pulse travels through concrete, the denser it is and with less pores, therefore better quality and strength. According to the above results as the $\mathrm{w} / \mathrm{c}$ ratio increases the concrete quality and strength decreases. With respect to graph 2 this indicates that the lower $\mathrm{w} / \mathrm{c}$ ratio, the better concrete is in terms of quality and strength.

\begin{tabular}{|l|l|}
\hline Ultrasonic Pulse Velocity $(\mathrm{km} / \mathrm{s})$ & Quality of concrete \\
\hline Above 4.57 & Excellent \\
\hline Between 4.57 and 3.66 & Good \\
\hline Between 3.66 and 3.05 & Fair \\
\hline Between 3.05 and 2.13 & Poor \\
\hline Below 2.13 & Very poor \\
\hline
\end{tabular}

Table 7. The table shows the relationship between ultrasonic pulse velocity and the quality of concrete. 


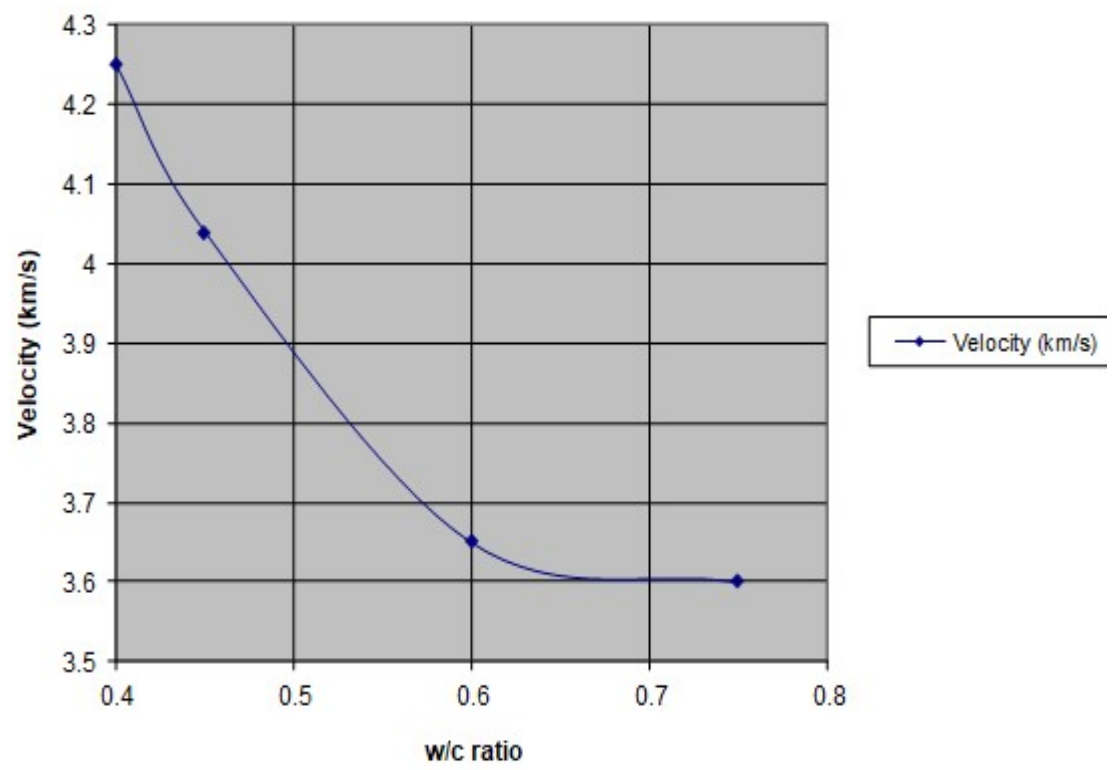

Graph 2. The graph shows the velocity vs. w/c ratio.

\section{ISAT - Initial surface absorption test}

Tables 11 to 14 shows the initial surface absorption test results obtained in the lab for concrete specimens of $0.4,0.45,0.60$ and $0.75 \mathrm{w} / \mathrm{c}$ ratios.

\begin{tabular}{|l|l|l|l|}
\hline \multicolumn{1}{|c|}{ Reading $[\mathrm{mm}]$} & \multicolumn{1}{c|}{ Time $[\mathrm{min}]$} & Duration $(\mathrm{sec})$ & \multicolumn{1}{c|}{ Distance $(\mathrm{mm})$} \\
\hline 58 & 9 & & 3.65 \\
\hline 61.5 & 10 & 60 & 3.5 \\
\hline 65.3 & 11 & 60 & 3.8 \\
\hline
\end{tabular}

Table 8. Results of initial surface absorption test for $0.40 \mathrm{w} / \mathrm{c}$ ratio.

${ }^{*}$ Calibration factor 3.605

**ISAT value $13.15(\mathrm{ml} / \mathrm{m} 2 / \mathrm{s})$ 


\begin{tabular}{|l|l|l|l|}
\hline \multicolumn{1}{|c|}{ Reading $[\mathrm{mm}]$} & Time $[\mathrm{min}]$ & Duration $(\mathrm{sec})$ & Distance $(\mathrm{mm})$ \\
\hline 3 & 9 & & 12 \\
\hline 15 & 10 & 60 & 12 \\
\hline 27 & 11 & 60 & 12 \\
\hline
\end{tabular}

Table 9. Results of initial surface absorption test for $0.45 \mathrm{w} / \mathrm{c}$ ratio.

${ }^{*}$ Calibration factor 3.367

**ISAT value $40.4(\mathrm{ml} / \mathrm{m} 2 / \mathrm{s})$

\begin{tabular}{|l|l|l|l|}
\hline \multicolumn{1}{|c|}{ Reading $[\mathrm{mm}]$} & \multicolumn{1}{c|}{ Time $[\mathrm{min}]$} & Duration $(\mathrm{sec})$ & \multicolumn{1}{c|}{ Distance $(\mathrm{mm})$} \\
\hline 2 & 9 & & 5.9 \\
\hline 8 & 10 & 60 & 6 \\
\hline 13.8 & 11 & 60 & 5.8 \\
\hline
\end{tabular}

Table 10. Results of initial surface absorption test for $0.60 \mathrm{w} / \mathrm{c}$ ratio.

${ }^{*}$ Calibration factor 3.367

**ISAT value $19.87(\mathrm{ml} / \mathrm{m} 2 / \mathrm{s})$

\begin{tabular}{|l|l|l|l|}
\hline \multicolumn{1}{|c|}{ Reading $[\mathrm{mm}]$} & \multicolumn{1}{c|}{ Time $[\mathrm{min}]$} & Duration $(\mathrm{sec})$ & Distance $(\mathrm{mm})$ \\
\hline 57 & 9 & & 23 \\
\hline 80 & 10 & 60 & 23 \\
\hline
\end{tabular}

Table 11. Results of initial surface absorption test for 0.75 w/c ratio.

${ }^{*}$ Calibration factor 3.605

**ISAT value $82.9(\mathrm{ml} / \mathrm{m} 2 / \mathrm{s})$

Tables 8 to 11 shows the results obtained in lab for initial surface absorption test with $\mathrm{w} / \mathrm{c}$ ratios concrete specimens of $0.40,0.45,0.60$ and 0.75 . As shown in table 8 for $0.4 \mathrm{w} / \mathrm{c}$ ratio the ISAT value was $13.15 \mathrm{ml} / \mathrm{m} 2 / \mathrm{s}$ with a calibration factor of 3.605. Furthermore, this value seems to be reasonable. On the other hand, the $0.45 \mathrm{w} / \mathrm{c}$ ratio as presented in table 9 illustrates an ISAT value of $40.4 \mathrm{ml} / \mathrm{m} 2 / \mathrm{s}$ and a calibration of 3.367 . As the $0.60 \mathrm{w} / \mathrm{c}$ ratio in table 10 is presented with an ISAT of $19.87 \mathrm{ml} / \mathrm{m} 2 / \mathrm{s}$, this value seems to be wrong because it does not match with the other ISAT values of different w/c ratio specimens. In addition to this, the ISAT value should be increasing instead of decreasing as the $\mathrm{w} / \mathrm{c}$ ratio increases. Finally and never the least, the $0.75 \mathrm{w} / \mathrm{c}$ ratio concrete cube (Table 11) showed the highest ISAT value among the other concrete specimens of different w/c ratio with $82.9 \mathrm{ml} / \mathrm{m} 2 / \mathrm{s}$.

It is believed that higher the ISAT value, the better the concrete is in terms of porosity. Apart from the ISAT value for $0.60 \mathrm{w} / \mathrm{c}$ ratio, the results show that as the $\mathrm{w} / \mathrm{c}$ ratio increase 
the ISAT value increase. According to graph 3 this indicates that the lower w/c ratio the better concrete is in terms of porosity.

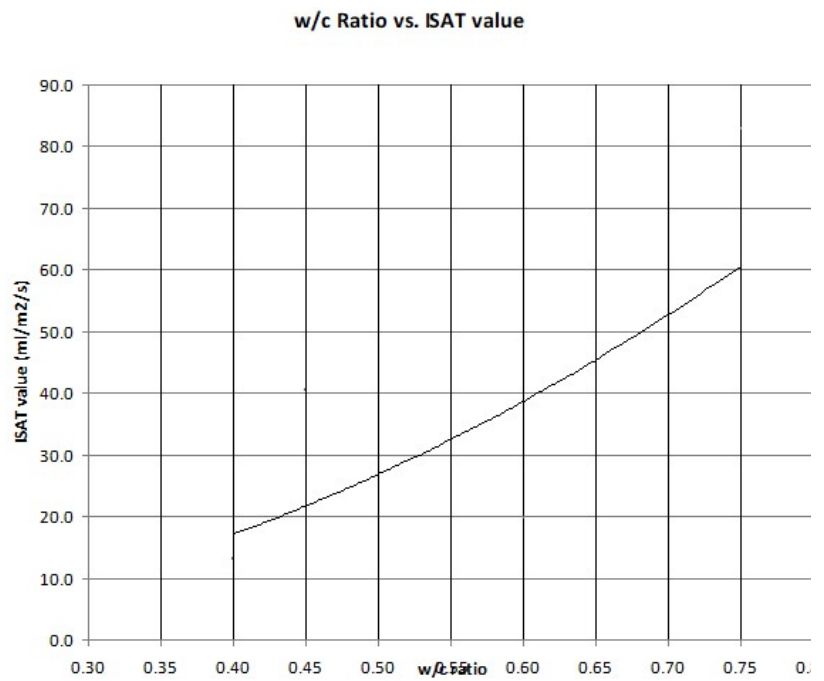

Graph 3. The graph shows the w/c ratio vs. ISAT value.

\section{Figg air test}

Tables 12 to 15 shows the Figg air test results obtained in the lab for concrete specimens of $0.4,0.45,0.60$ and $0.75 \mathrm{w} / \mathrm{c}$ ratios. The air permeability has been calculated using equation 2 below.

Air permeability $=($ Average time for hole $1+$ Average time for hole 2$) / 2$

\begin{tabular}{|l|l|l|}
\hline \multicolumn{1}{|c|}{ Hole No. } & \multicolumn{1}{|c|}{ Pime } & \multicolumn{1}{c|}{ Pressure } \\
\hline 1 & $50 \rightarrow 55$ & 2.4 \\
\hline & $50 \rightarrow 55$ & 3.2 \\
\hline & $50 \rightarrow 55$ & 2.7 \\
\hline & $50 \rightarrow 55$ & 2.4 \\
\hline & & Average 2.7 \\
\hline 2 & $50 \rightarrow 55$ & 2.8 \\
\hline & $50 \rightarrow 55$ & 3.3 \\
\hline & $50 \rightarrow 55$ & 3.8 \\
\hline & $50 \rightarrow 55$ & 4.0 \\
\hline & $50 \rightarrow 55$ & 3.5 \\
\hline & & Average 3.5 \\
\hline
\end{tabular}

Table 12. Results of air test for $0.40 \mathrm{w} / \mathrm{c}$ ratio.

* Air permeability $=(2.7+3.5) / 2=3.1$ seconds 


\begin{tabular}{|l|l|l|}
\hline \multicolumn{1}{|c|}{ Hole No. } & \multicolumn{1}{|c|}{ Pressure } & \multicolumn{1}{c|}{ Time } \\
\hline 1 & $60 \rightarrow 55$ & 18.3 \\
\hline & $60 \rightarrow 55$ & 23.1 \\
\hline & $60 \rightarrow 55$ & 22.6 \\
\hline & $60 \rightarrow 55$ & 22.1 \\
\hline & & Average 21.5 \\
\hline 2 & Not measures & \\
\hline
\end{tabular}

Table 13. Results of fig air test for $0.45 \mathrm{w} / \mathrm{c}$ ratio.

* Air permeability $=21.5$ seconds

\begin{tabular}{|l|l|l|}
\hline \multicolumn{1}{|c|}{ Hole No. } & \multicolumn{1}{|c|}{ Pressure } & \multicolumn{1}{c|}{ Time } \\
\hline 1 & $65 \rightarrow 60$ & 3.12 \\
\hline & $65 \rightarrow 60$ & \multicolumn{1}{|c|}{2.93} \\
\hline & $65 \rightarrow 60$ & 2.90 \\
\hline & $65 \rightarrow 60$ & 2.95 \\
\hline 2 & & Average 3 \\
\hline & $65 \rightarrow 60$ & 3.47 \\
\hline & $65 \rightarrow 60$ & 4.66 \\
\hline & $65 \rightarrow 60$ & 4.91 \\
\hline & $65 \rightarrow 60$ & 4.52 \\
\hline & & Average 4.4 \\
\hline
\end{tabular}

Table 14. Results of fig air test for $0.60 \mathrm{w} / \mathrm{c}$ ratio.

* Air permeability $=(3+4.4) / 2=3.7$ seconds 


\begin{tabular}{|l|l|l|}
\hline \multicolumn{1}{|c|}{ Hole No. } & \multicolumn{1}{|c|}{ Pressure } & \multicolumn{1}{c|}{ Time } \\
\hline 1 & $55 \rightarrow 50$ & 2.16 \\
\hline & $65 \rightarrow 60$ & 2.15 \\
\hline & $65 \rightarrow 60$ & 2.17 \\
\hline & & Average 2.2 \\
\hline 2 & $65 \rightarrow 60$ & 2.04 \\
\hline & $65 \rightarrow 60$ & 2.32 \\
\hline & $65 \rightarrow 60$ & 2.24 \\
\hline & & Average 2.2 \\
\hline
\end{tabular}

Table 15. Results of fig air test for $0.75 \mathrm{w} / \mathrm{c}$ ratio.

* Air permeability $=(2.2+2.2) / 2=2.2$ seconds

Tables 12 to 15 shows the results obtained in lab for figg air test with w/c ratios concrete specimens of $0.40,0.45,0.60$ and 0.75 . As exposed in table 12 for $0.4 \mathrm{w} / \mathrm{c}$ ratio the air average permeability value was 3.1 seconds. Furthermore, the results for $0.45 \mathrm{w} / \mathrm{c}$ ratio as presented in table 13, shows air permeability with 21.5 seconds. Table 14 illustrates an air permeability of 3.7 seconds for a w/c ratio of 0.60 . The results for $0.75 \mathrm{w} / \mathrm{c}$ ratio as revealed in table $15 \mathrm{de}$ monstrates air permeability with 2.2 seconds.

It is known that if the air permeability value is less than 25 seconds, then the concrete is considered to be poor in terms of durability. Moreover, if the air permeability is less than 25 seconds then this shows that there were plenty of pores in the concrete leading to quick diffusion of the air. Since the air permeability increases the durability increases, this indicates that the figg air test results were absolutely wrong, illogical and not close to reality.

\subsection{Comparing Results}

The results of all in-situ tests that were carried out has been summarized and shown in table 16. The results of rebound hammer and ultrasonic pulse velocity showed a uniform relationship between compressive strength, velocity and w/c ratio. This indicates that as the $\mathrm{w} / \mathrm{c}$ ratio decrease, both the compressive strength and velocity increases, therefore better quality of concrete in terms of strength. Alternatively, the increase in w/c ratio leads to a decrease in the rebound number and an increase in ultrasonic pulse velocity. By referring to graph 4 which presents the relation between rebound hammer and ultrasonic pulse velocity, it shows that as the compressive strength increases, the ultrasonic pulse velocity increases. Therefore, the increase in ultrasonic velocity leads to denser concrete with a good quality and strength. On the other hand, the results for initial surface absorption and fig air were incorrect and showed no relation with each other, or with other tests. Thus, they cannot be compared with other tests. Usually, the initial surface absorption test and fig air test can be compared with each other to find a relation between w/c ratio, air permeability and time. In theory, the relation should show an increase in permeability with a decrease in time, which leads to a good concrete in terms of porosity and durability. Consequently, as the w/c ratio decreases, the better the concrete is in terms of strength and permeability. Generally speaking, the concrete permeability is affected by moisture content of concrete. 


\begin{tabular}{|l|l|l|l|l|l|}
\hline \multirow{2}{*}{ Test } & \multicolumn{4}{c|}{ w/c Ratio } & \multirow{2}{*}{ Test set to find } \\
\cline { 2 - 6 } & 0.4 & 0.45 & 0.6 & 0.75 & \\
\hline Rebound hammer (Strength in N/mm ${ }^{2}$ ) & 56 & 51 & 42 & 32 & Strength \\
\hline Ultrasonic pulse velocity $(\mathrm{km} / \mathrm{s})$ & 4.24 & 4.04 & 3.65 & 3.6 & Quality \\
\hline Initial surface absorption $\left(\mathrm{ml} / \mathrm{m}^{2} / \mathrm{s}\right)$ & 13.15 & 40.4 & 19.87 & 82.9 & Porosity \\
\hline Figg air (Seconds) & 3.1 & 21.5 & 3.7 & 2.2 & Air permeability \\
\hline
\end{tabular}

Table 16. Results of all in-situ tests carried out.

Rebound hammervs. Ultrasonic pulse velocity

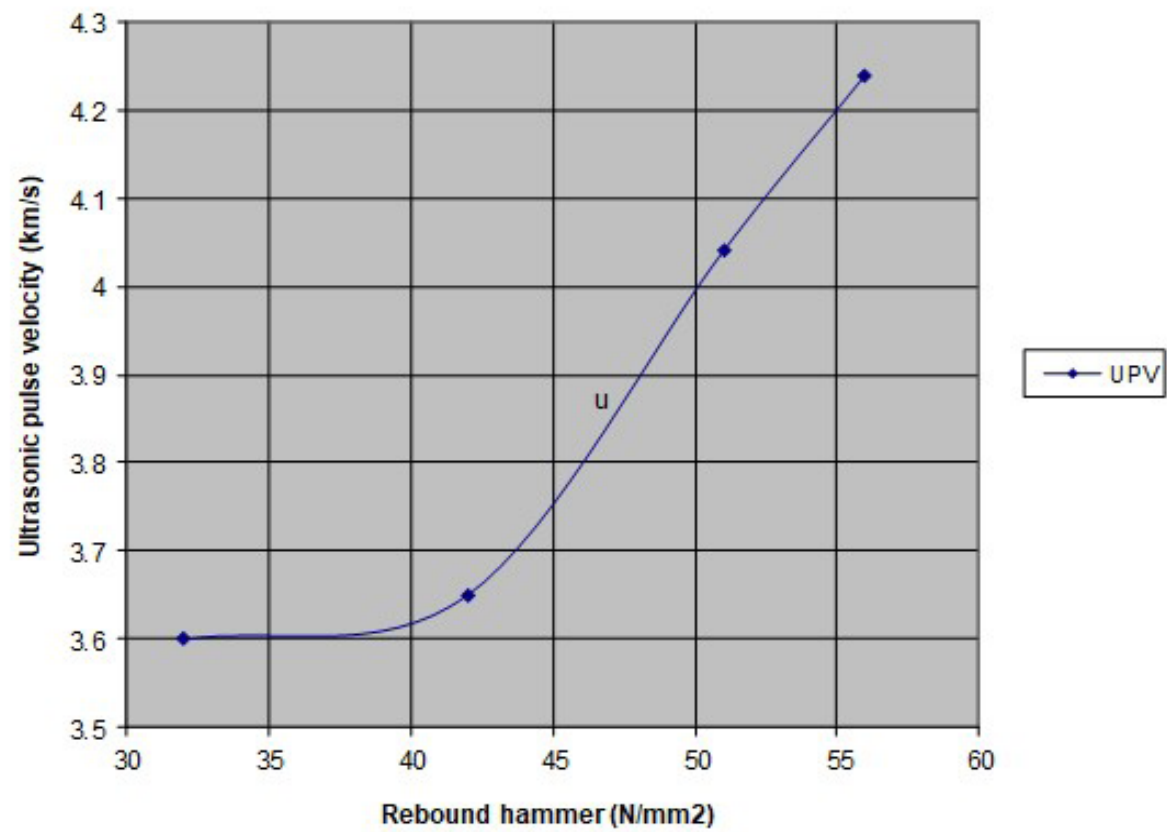

Graph 4. Rebound hammer vs. ultrasonic pulse velocity.

\section{CONCLUSION}

The in-situ testing lab was set to find the quality of concrete in terms of strength, porosity and permeability. It was found that the strength of concrete effects quality depending on w/c ratio. So as the w/c ratio decreases both compressive strength and velocity increases. Thus, higher strength means better quality.

The advantages of in-situ testing are that they are simple methods of testing, quick in operation and cost effective. Conversely, each test has its own limitations. For example, the limitation of initial surface absorption and figg air tests are the moisture content of concrete.

The results for rebound hammer test indicated a good concrete strength with values of $56,51,42$ and $32 \mathrm{~N} / \mathrm{mm} 2$ with respect to $0.40,0.45,0.60$ and $0.75 \mathrm{w} / \mathrm{c}$ ratios. Additionally, the results for ultrasonic pulse velocity showed good concrete in terms of quality with value of $4.24,4.04,3.65$ and $3.6 \mathrm{~km} / \mathrm{s}$. On the other hand, the results for initial surface ab-sorption 
and figg air tests demonstrated no relation with each other or with other results. The figg air results were not accurate and showed lots of errors. This may be due to many factors such as test conditions and method, concrete variability or operator skill. In addition to this, there may be issues with figg air apparatus, such as, an escape of the air from the concrete hole and this is leading to false results. The results established a good concrete strength and quality apart from illogical results of concrete porosity and air permeability. According to in-situ testing results the following has been concluded:

- The increase in $\mathrm{w} / \mathrm{c}$ ratio leads to a decrease in compressive strength and ultrasonic pulse velocity. Thus, lower w/c ratio gives a better concrete strength in terms of quality.

- The quicker the ultrasonic pulse travels through concrete indicates that the concrete is denser, therefore, better quality.

- The lower initial surface absorption value indicates a better concrete with respect to porosity.

- The concrete porosity is considered to be poor if air permeability is less than 25 seconds (ISAT).

- The relation between rebound hammer and ultrasonic pulse tests is that, an increase in compressive strength leads to increase in the ultrasonic pulse velocity.

- The w/c ratio plays an important role in the strength and permeability of concrete.

There is a relationship between strength tests and permeation tests but it is hard to determine due to some false results obtained in the lab for initial surface absorption and Figg air tests. In general, if the $\mathrm{w} / \mathrm{c}$ ratio decreases with a decrease in permeability and an increase in compressive strength, then it can be that there is a relationship between two tests. The results could have been improved by increasing the number of concrete specimens for testing and by maintain better conditions.

\section{ACKNOWLEDGEMENT:}

I would like to thank my family, my mother, my father and my brothers for their moral support. Many thanks to Dr. Judith Halliday a senior lecturer at the University of Dundee and to all the staff of the Department of Civil Engineering in the University of Dundee for their technical support for providing the material and for making the concrete structures laboratory available for conducting this experimental study. 


\section{REFERENCES}

Abdel Rahim, K. (2019). EXPERIMENTAL STUDY ON THE MIX DESIGN AND FRESH PROPERTIES OF CONCRETE. Australian Journal of Science and Technology, 3(1), 22086404. doi:http://www.aujst.com/vol-3-1/04-AJST-70_REV.pdf

Abdel Rahim, K. (2019). CONCRETE SPECIFICATIONS AND METHODS OF QUALITY TESTING, Asian Institute of Research, Engineering and Technology Quarterly Reviews, 2(1), 2622-9374. doi:https://www.asianinstituteofresearch.org/ETQRarchives/ConcreteSpecification-and-Methods-of-Quality-Testing-

Abdel Rahim, K. (2019). EXPERIMENTAL STUDY: DETERMINATION OF CONCRETE REINFORCEMENT CONDITIONS. The Journal of Engineering and Exact Sciences, 5(3), 0212-0219. doi:https://doi.org/10.18540/jcecvl5iss3pp0212-0219

Bungey, J. H., Millard, S. G. and Grantham, M. et al. (2006). Testing of concrete in structures, London; New York, Taylor \& Francis.

Neville, A. M. (1996). Properties of concrete, New York, Wiley.

Halliday, J. (2010). Assessment of concrete structures, Summary of the test methods to be used in labs. University of Dundee, Dundee, UK.

Halliday, J. (2010). Assessing Quality and Durability of Concrete. Lecture 3 Notes Concrete Assessment. University of Dundee, Dundee, UK.

The British Standards Institution (BSI), (1988). BS 1881: Part 124: 1988 - Methods of analysis of hard-ened concrete, The British Standards Institution (BSI), London.

The British Standards Institution (BSI), (1986). The British Standard, BS 1881: Part 201: 1986 -Guide to the use of nondestructive methods of test for hardened concrete, The British Standards Institution (BSI), London.

The British Standards Institution (BSI), (1986). The British Standard, BS 1881: Part 202 Determination of Rebound Number, The British Standards Institution (BSI), London.

The British Standards Institution (BSI), (1986). The British Standard, BS 1881: Part 203

- Recommendations for measurement of ultrasonic pulses in concrete, The British Standards Institution (BSI), London.

The British Standards Institution (BSI), (1996). The British Standard, BS 1881: Part 208: 1996 - Recommendations for the determination of the initial surface absorption of concrete, The British Standards Institution (BSI), London.

The Concrete Society, (2000). Diagnosis of deterioration in concrete structures, Technical Report No.54, Berkshire, Crowthorne. 